\title{
O PROJETO LITERÁRIO DE ANTÓNIO ALVES REDOL E O SEU DESTINATÁRIO: NOTA SOBRE A AURORA DO NEORREALISMO LITERÁRIO PORTUGUÊS ${ }^{13}$
}

\author{
Antony Cardoso Bezerra (UFRPE) \\ bezerra.a.c@gmail.com
}

Ao amigo e mestre José Rodrigues de Paiva.

[...] é da sabedoria dos povos que os auditórios gostam de suprimir o objeto da sua admiração logo que se saturam de admirá-lo. (NAMORA, 1970, p. 857)

Considerada mais expressivamente na condição de partícipe ativa na construção do texto literário/ficcional, a instância receptora - ou, simplesmente, o leitor - é matéria privilegiada de investigações em não poucas correntes da Teoria da literatura; em especial, a partir da segunda metade do séc. 20. No juízo de N. W. Sodré (1965, p. 29), por exemplo, os três aspectos fundamentais do estudo da literatura em sua historicidade e em seu sentido social seriam, precisamente, o autor (quem faz), o leitor (quem consome) e os meios de transmissão (como se comunica). ${ }^{14}$ Tan-

\footnotetext{
${ }^{13}$ Este trabalho, apresentado em versão preliminar no 2.0 Seminário Paradigmas do Ensino de Literatura (18 a 21 de outubro de 2011, Centro de Educação da Universidade Federal de Pernambuco), resulta de inquirições realizadas no âmbito do projeto de pesquisa $A$ Ideia do Realismo na Literatura Portuguesa: o romance entre 1927 e 1974, conduzido na Universidade Federal Rural de Pernambuco e integrado às atividades do Grupo de Investigações em Filologia Ibérica.

14 Ocupando-se especificamente do circuito da comunicação literária no Neorrealismo português, problema central no presente artigo, Losa observa: "Um dilema com que os escritores neorrealistas tiveram de conviver e que parece ser importante para explicar a sua hesitação quanto ao método e estilo de escrita a adotar foi a questão sociológica de estabelecer quem escrevia para quem." (LOSA, 1999, p. 185)
} 
tas sejam as abordagens, entrementes, quantas serão as conceituações e os níveis de análise; bem como, não é o caso de desprezá-las, as nomenclaturas.

No presente estudo, em que não se negam as contribuições da estética da recepção, da semiótica e, mesmo, da sociologia da leitura/literatura para o estabelecimento e a conceituação dos possíveis receptores ficcionais ou reais - de uma composição literária, visa-se a uma problematização preliminar de uma categoria que se propõe chamar "destinatário" conforme sinalizada/exposta no projeto artístico do escritor neorrealista português António Alves Redol (*1911 - †1969).

Para o desenvolvimento do exame, propõe-se um percurso que tente caracterizar a instância receptora do texto literário (com ênfase no conceito de destinatário há pouco ventilado), situe historicamente o nascedouro do movimento denominado Neorrealismo Literário Português e as suas relações com o materialismo dialético, bem como, por fim, analise passagens manifestas de escritos de Redol que revelem qual leitor teve em foco quando compôs as suas primeiras narrativas. Trata-se de obras que, no dizer de Salema (1980, p. 48) - e na esteira do próprio Redol -, compõem um primeiro ciclo da obra do romancista e de que fazem parte Gaibéus (1939), Marés (1941), Avieiros (1942) e Fanga (1943). Em específico, o corpus é integrado pelos prefácios que, na década de 1960, Redol compôs para Gaibéus, Avieiros e Fanga; são textos, portanto, de cariz retrospectivo. Também se contemplam, à guisa de preâmbulo, aspectos da conferência intitulada “Arte", proferida pelo autor em 1936.

Antes de descer às especificidades conceituais que podem dizer respeito ao receptor (particularmente, aqui, o da narrativa ficcional), cumpre reconhecer uma bifurcação referida por V. Jouve:

[...] o receptor de um texto é ao mesmo tempo o leitor real, cujos traços psicológicos, sociológicos e culturais podem variar infinitamente, e uma figura abstrata postulada pelo narrador pelo simples fato de que todo texto dirige-se necessariamente a alguém. (JOUVE, 2002, p. 36)

Em termos, o primeiro ponto da escala, conforme adiante se vê, responde mais essencialmente aos interesses relacionados ao fulcro do trabalho. O segundo, recorrente quando se pensa nos estudos de teoria da literatura, recebe mais de um nome e, nele, reconhece-se mais de um alcance. No dizer do narratólogo G. Genette,

Como o narrador [a instância enunciadora ficcional], o narratário é um dos elementos da situação narrativa, e coloca-se, necessariamente, no mesmo nível diegético; quer dizer que não se confunde mais, a priori, com o leitor 
(mesmo virtual) de que o narrador com o autor, pelo menos não necessariamente. (GENETTE, 1996, p. 258)

Ora, se toda enunciação precisa de quem a receba (nem que seja o próprio enunciador), é necessário que o narrador ficcional tenha a sua contraparte, neste caso, o destinatário igualmente ficcional, o narratário, uma resposta à seguinte pergunta: a quem fala o narrador? No entanto, conforme Jouve revela, a discussão sobre esse receptor abstrato, ficcional, tem, ainda, desdobramentos de maior complexidade; ou, ao menos, que acarretam mais implicações (cf. JOUVE, 2002, p. 43-47).

Dentre os fatores problematizados pelo estudioso francês, dois podem ser mencionados: o "leitor-modelo", de U. Eco, e o "leitor implícito", de W. Iser, conceitos que se desenvolveram/modificaram no seio da própria teorização dos autores. O leitor-modelo é "um conjunto de instruções textuais, apresentadas pela manifestação linear do texto precisamente como um conjunto de frases ou de outros sinais." (ECO, 1999, p. 22) Por seu turno, o leitor implícito "corporifica todas as predisposições necessárias para que uma obra literária exerça o seu efeito; predisposições formuladas não por uma realidade empírica e exterior, mas pelo texto ele mesmo." (ISER, 1978, p. 163). ${ }^{15}$ Ambos os conceitos estão firmemente calcados na estrutura textual e acabam por indicar uma espécie de persona que se emprega pelo leitor real, à guisa de uma assinatura do contrato ficcional.

Noutro nível, estaria o primeiro dos elementos suscitados na bifurcação há pouco informada - o leitor real, que, "longe de ser desencarnado, é uma pessoa inteira que, como tal, reage plenamente às solicitações psicológicas e à influência ideológica do texto." (JOUVE, 2002, p. 49) Dentre outras abordagens, esse leitor seria alvo, por exemplo, das investigações de uma sociologia da leitura/literatura, responsável por captar os anseios e os preenchimentos que um leitor efetivo faria das lacunas presentes em determinada obra ficcional.

Nem das propostas de Genette, Eco e Iser, mas também não do leitor real, ocupa-se esta investigação do projeto redoliano. Nem de narratário, leitor-modelo ou leitor implícito, porque o objeto de investigação é o discurso sobre a ficção, e não o discurso ficcional; nem do receptor efetivo, porque não se propõe um inquérito ao leitor de Redol (como se vê, por exemplo, em “Quem conhece Redol?”, 1970, p. 936-945).

${ }_{15}$ Trechos em língua estrangeira foram traduzidos ao Português. 
Muito por seu corpus, este artigo se volta a uma instância que se opta por nominar "destinatário", uma espécie de leitor intuído do texto literário. Trata-se de um leitor manifestamente referido pelo autor literário como aquele a quem se dirige sua produção, não no discurso ficcional (ou seja, não por meio de marcas/índices), mas, sim, nos discursos sobre a realidade (prefácios, ensaios, conferências etc.) Não é, portanto, parte de um modelo vinculado à narratologia, pois não é o receptor expresso/sugerido na narrativa que está em pauta. Menos ainda se apresenta como o receptor concreto do texto. Constitui-se, sim, como um leitor real, bem certo, mas que se apresenta como "figura" no sentido que Auerbach dá ao termo; ou seja, uma promessa de leitor que só pode ser efetivamente concretizada no plano histórico, por meio da recepção (cf. AUERBACH, 1997). Nesse caso, tanto a promessa quanto o cumprimento estão inseridos na materialidade do mundo e na história.

A partir das considerações de Reis acerca do processo de evolução literária, é possível enxergar o Neorrealismo Literário Português mais como "grupo" ou "movimento" do que, propriamente, como "geração" (REIS, 2001, p. 384; p. 387-388). Que os intelectuais e escritores responsáveis pela ascensão e afirmação da estética neorrealista pertencem a uma mesma faixa etária e que estabeleceram uma relação de conflitualidade com a tendência que os antecede - no caso, o chamado Presencismo ${ }^{16}$-, é bem verdade, e, aqui, tratar-se-ia de pensar mesmo numa geração. No entanto, a defesa que ora se faz parece amalgamar os autores no âmbito mais amplo de um projeto literário em seu desenvolvimento histórico, com os próprios criadores a modificarem/aprimorarem a exposição de suas convicções ideológico-artísticas ao longo das respectivas carreiras. ${ }^{17}$ Por isso, parece, melhor é pensar na coesão de um grupo e na

\footnotetext{
${ }^{16}$ A Presença, folha de arte e crítica, foi criada em 1927 por um grupo de estudantes coimbrãos e teve duas fases: da fundação a 1938 e de 1939 a 1940. Preza as individualidades e os seres de exceção, em detrimento da atribuição de um caráter social às manifestações artísticas (como se tal fosse possível).

${ }^{17}$ Assinale-se que o conceito de ideologia que integra o artigo - manifesta ou sub-repticiamente indicado no desenvolvimento deste - é aquele que, seguindo um viés marxista, "não é, em primeiro lugar, um conjunto de doutrinas; ela representa a maneira como os homens exercem seus papéis na sociedade de classes, os valores, as ideias e as imagens que os amarram às suas funções sociais e assim evitam que conheçam verdadeiramente a sociedade como um todo." (EAGLETON, 2011, p. 36) No que diz respeito à arte, no entanto, a ideologia não mantém "uma relação simples e simétrica [com] as mudanças na forma literária." (EAGLETON, 2011, p. 53) Passíveis de se associarem a esse viés, os neorrealistas portugueses, por exemplo, negam-se a dar as costas ao trabalho com a forma e com a linguagem literárias.
} 
organização de um movimento - em suas não poucas ramificações -, para, assim, firmar a tomada expressa de posição frente a um quadro que, aos artistas, assemelha-se insustentável pela concentração do poder nas mãos de poucos. Desse modo, parte-se de uma desagregação que leva à ruptura: (1) no plano político, com a ideologia de recortes fascistas do "Estado Novo"; (2) com o segundo Modernismo português (a Geração de Presença), no que à conjuntura artístico-literária diz respeito.

Se se intentar o estabelecimento (ou, em termos lenificados, uma sugestão) da baliza temporal que revele o nascedouro do Neorrealismo, a década de 1930 se apresenta como um momento-chave. Em que pese à antecedência do ficcionista Ferreira de Castro a muita questão que se tornará capital ao estatuto neorrealista - grosso modo, representado no modo realista de criação ficcional em combinação ao caráter denunciador das desigualdades sociais -, é, com efeito, em periódicos espraiados pelo país que se forja, pouco a pouco, o conjunto de diretrizes que norteará tanto a estética quanto o viés ideológico do movimento. Sobre o papel da articulação entre teoria e produção literária nesse contexto, afirma Reis:

[...] deve vincar-se que o período de mais fecunda produção teórica neorrealista corresponde justamente à fase mais intensa de criação literária do movimento em questão. Este fato mais não faz do que confirmar a noção de que a especulação teórica não constitui uma atividade apriorística, mas antes um labor fundamentado nas características do próprio discurso literário sujeito a teorização. (REIS, 1981, p. 31)

Noutros termos, disso, pode-se tirar uma ilação: o aprendizado sobre o que das criações ficcionais se diz (em sentido futurante ou retrospectivo, pouco importa) é útil no sentido de caracterizar a literatura em seu sentido lato. No caso particular do presente artigo, por exemplo, temse na conta de válida a análise do destinatário da obra literária conforme caracterizado em textos não ficcionais que saiam da pena do autor (isto é, Redol).

No sentido de se ilustrar a natureza das defesas feitas em periódicos, pode-se mencionar passagem de texto redigido, em 1935, por Quintinha e veiculado em $O$ Diabo, revista das mais decisivamente ligadas ao ideário neorrealista (daí sua combatividade) no que se convencionou chamar de primeira fase do movimento (1935-1950):

Antes de mais nada, o artista, como pessoa humana que é, não deve ignorar o sofrimento da Humanidade, nem pode alhear-se do seu drama. Se o fizer confunde-se com os egoístas vulgares, e só muito dificilmente, e ainda com o supremo encanto da sua arte, nos poderá compensar da sua deserção. $\mathrm{O}$ artista que fechar os olhos para não ver o drama social corre o risco de se colocar fo- 
ra da Vida, porque esse drama, com suas causas e consequência econômicas, domina a existência do indivíduo, em todo o mundo. (QUINTINHA apud REIS, 1981, p. 81-82)

Sutileza é o que não há no posicionamento do autor - não à ênfase nos desvãos da individualidade conforme trabalhados pela prosa de ficção e pela poesia presencistas, e sim a uma arte manifestamente engajada na mudança de um quadro político-social em que o obscurantismo dita normas. É de se notar que a defesa se alinha muito nitidamente a uma motivação de ascendência marxista, traduzida, por exemplo, no pensamento de Trotski, um dos ideólogos da Revolução Russa.

É ridículo, absurdo e mesmo estúpido, no mais alto grau, pretender que a arte permaneça indiferente às convulsões da época atual [1924]. Os homens preparam os acontecimentos, realizam-nos, sofrem os efeitos e se modificam sob o impacto de suas reações. A arte, direta ou indiretamente, reflete a vida dos homens que fazem ou vivem os acontecimentos. Isso é verdadeiro para todas as artes, da mais monumental à mais íntima. (TROTSKI, 2007, p. 35)

Possuidores de tom similar, escritos de Gladkhov, Górki, Plekhanov et al., quase sempre em traduções ao francês ou ao castelhano, circularam clandestinamente em Portugal à altura da eclosão do Neorrealismo. Num viés que historiciza as manifestações artísticas, os pensadores e escritores russos não deixam de ser uma espécie de motivadores distantes dos intelectuais e literatos portugueses que se contrapõem à ordem estabelecida das coisas e que, por meio da escrita (mas não apenas), tentam lançar bases para uma sociedade equânime. Transformada em profissão de fé, a intervenção social por meio da arte terá, com efeito, uma dupla face: a que conclama à produção e o produto em si, cuja primeira espécie de fôlego é, precisamente, o romance Gaibéus, de autoria do ficcionista que se contempla neste artigo.

Conforme já se deve ter evidenciado, propósitos capitais dos autores neorrealistas portugueses - ao menos, num primeiro momento - repousaram numa tentativa de recuperar criticamente o Realismo oitocentista e, ao fazê-lo, incidir numa realidade circundante que, aos escritores, parecia desprovida de perspectivas, pois que penetrada em todos os sentidos pela mão de ferro do "Estado Novo" salazarista. Nas palavras de Losa, trata-se de uma motivação de

[...] colocar o sujeito da enunciação narrativa a tomar partido intradiegeticamente, por um dos lados do conflito representando no texto e a de persuadir o leitor, ele também, a tomar esse mesmo partido.

Esta atitude militante e esta fé, quiçá romântica, na possibilidade de haver textos ficcionais que não só refletissem uma causa em marcha no mundo ex- 


\section{FACULDADE DE FORMAÇÃO DE PROFESSORES}

tratextual, mas também interviessem, de modo quase imediato, nessa causa, criando-lhe novos adeptos, pode inclinar-nos a situar os escritores neorrealistas mais perto do fulgor experimentalista dos Modernistas do que da ponderação crítica e da atitude não intervencionista dos assim ditos "grandes realistas". (LOSA, 1999, p. 181-182)

É bem essa nota que dá o tom de uma espécie de estreia de Redol como intelectual voltado para a causa e para as coisas que reconhece como sendo do seu povo. Na terra natal, Vila Franca de Xira, o jovem intelectual, contando então 25 anos (era o ano de 1936), profere uma conferência sobre o tema "Arte" no Grêmio Artístico Vilafranquense (SILVA, 1990, p. 80-81). Para o aprendiz de escritor, à altura - como, de resto e coerentemente, sustentará em todo o seu percurso literário -, "A arte é determinada em todos os seus aspectos pelo regime econômico e pelo nível técnico social." (REDOL apud SILVA, 1990, p. 82) Fortemente influenciado por um marxismo de segunda ou terceira mão, em fontes sempre traduzidas e que tendiam a simplificar em demasia o projeto do pensador alemão, Redol incita o seu público a dirigir um olhar crítico às manifestações artísticas que chama de formalistas, em que o egoísmo se traveste na defesa de uma "arte pela arte" (REDOL, 1990, p. 82-83). Claro é, aqui, o ataque às tendências presencistas, que reafirmaram as contribuições de autores como Paul Valéry e Marcel Proust na literatura do país.

Silva, na apresentação que faz do chamado Grupo Neorrealista de Vila Franca de Xira (de que Redol participa na condição de líder), destaca o fato de que, nesse contexto, o futuro autor de Gaibéus ter sido "profundamente sensibilizado por uma nova estética, seguindo-a como integrada no contexto ideológico em que se comprometera e militava [...]." (SILVA, 1990, p. 84) Isso se verifica facilmente em passagens da conferência redoliana, em que se pode ler: "A arte deve contribuir para o desenvolvimento da consciência e para melhorar a ordem social" ou "Todos os assuntos devem servir em proveito do homem, se não querem ser uma vã e ociosa ocupação [...]" (REDOL apud SILVA, 1990, p. 84). De caráter nitidamente prospectivo em relação às efetivações artísticas do Neorrealismo, o conjunto de asserções do romancista em devir muito bem se associa ao ideário dominante do movimento, não apenas no que diz respeito ao fazer literário, mas também numa sinalização do público a que se visa e, ainda mais, que sentimentos caberiam à literatura despertar neste. Trata-se de uma "arte de conversão", no dizer de Losa (1999, p. 189).

Contemporânea à eclosão das primeiras manifestações neorrealistas, a defesa feita por Redol, sem dúvida, parece tão adequada ao mo- 
mento quanto ignorante da efetiva conjuntura portuguesa, em que pulula o analfabetismo e em que o mercado editorial não é senão incipiente (cf. MEDEIROS, 2010, p. 43-56). Além disso, conforme revela a já referida Losa, os regionalismos que se empregavam nas obras ficcionais como meio de aproximação ao vulgo, em verdade, não atingirem o propósito inicial, de vez que os falares variavam significativamente de região a região portuguesa. O público efetivo, assim, seria muito mais o de pessoas escolarizadas e cultas, que leem as obras em condição de avaliadores (LOSA, 1999, p. 190-191). Porque futurante, entretanto, não parece ser, o objetivo de Redol, descabido.

Vale, agora, verificar a retrospectiva que o romancista faz desse mundo e do que o sucede muito proximamente, com os romances Gaibéus, Avieiros e Fanga, os quais, ao lado de Marés (1941), formariam uma primeira etapa da ficção do autor, quando considera Fanga uma "espécie de primeira síntese na [sua] obra" (REDOL, 1980, p. 31). Para fins de comentário, lança-se mão de alguns excertos dos prefácios escritos por Redol em 1963 (“À Maneira de Prefácio”, Fanga), em 1965 ("Breve Memória para os que Têm Menos de 40 Anos ou para Quantos já Esqueceram o que Aconteceu em 1939”, Gaibéus) e em 1967 ("Breve História de um Romance", Avieiros).

No texto escrito para comentar extensivamente o nascedouro do Neorrealismo e a sua posição dentro do movimento - no caso, o prefácio a Gaibéus, Redol inclui um pequeno excurso biográfico, indicando, inclusive, os seus primeiros passos em letra impressa, dados no periódico O Diabo:

Ali criei a seção "De Sol a Sol", onde publiquei crônicas e contos ribatejanos, confundindo rebuscamento com estilo, num amálgama de poesia romântica e de Fialho, de barroquismo e de certo tom melodramático que correspondiam, por um lado, à falsa ideia de que "escrever difícil" seria o objetivo supremo de um verdadeiro escritor, e, por outro, à exaltação com que sentia os problemas das personagens a que aderira por origem familiar e por decisão de consciência premeditada. (REDOL, 1965, p. 21-22)

Efetivo caderno de exercícios do escritor em devir, o conjunto de textos veiculados na revista conteria, na visão de Salema, "um espontâneo lirismo popular [...], com a sugestão animada da natureza que o Tejo comanda na lezíria e da gente do povo que a habita." (SALEMA, 1980, p. 29) Isso é bem verdade, tanto que essa produção breve desaguaria em Glória: uma aldeia do Ribatejo (1938), estudo monográfico que enfoca a região que permearia a obra do autor. Do comentário de Redol sobre seu aprendizado com as letras, destaca-se a tentativa de escrever difícil (pa- 
tente nos modelos manifestos - o labiríntico Fialho de Almeida e a estética barroca). Ainda que o destinatário suscitado pela literatura como missão social fosse o vulgo (cf. SALEMA, 1980, p. 28), muito bem traduzida na adesão às causas dos simples, Redol não parece ter a dimensão precisa sobre como se expressar. É essa, ao menos, a visão do homem amadurecido que analisa, retrospectivamente, a condição do aprendiz. $\mathrm{Na}$ sequência de "Breve Memória para os que Têm Menos de 40 Anos ou para Quantos já Esqueceram o que Aconteceu em 1939", essa dialética que não resulta em síntese volta à baila:

O meu coração colocara-se com veemência ao lado do povo. Essa paixão turvava-me, talvez, a clareza da prosa, traindo o aprendiz de escritor que só numa escorreita simplicidade se poria à altura dos temas que conhecia e elegera. Mas não era possível, a quem então se metera, por inteiro, na batalha pela dignificação dos homens aviltados, ganhar a perspectiva lúcida naquele mínimo de distância que leva o escritor a dominar o assunto, sem que lhe deturpe as equivalências no plano estético. (REDOL, 1965, p. 22)

Só posteriormente se daria conta de que a representação do mundo à sua volta, para ser-lhe equivalente, teria de ser a da simplicidade e a da fluência. Só assim se alcançaria a conjunção entre forma e fundo que pode fazer da expressão literária um todo orgânico. E, à mistura, conforme traço marcante dessa literatura, abre-se espaço para uma relativização dos pontos de vista, usual nos Modernismos e convertida, em Redol, na adesão à causa das personagens desvalidas.

Pela possibilidade da reedição de seus textos, o autor não se furtou a sutilmente reparar a expressão literária, conforme confessa em "Breve História de um Romance", o prefácio a Avieiros:

Nesta variação sobre um tema de 1940 estabeleci um compromisso. Mantenho o tom da 1. ${ }^{\mathrm{a}}$ edição, mas sirvo-o com outra ferramenta afeiçoada à gesta popular. Gostaria de a ler aos mesmos que ouviram da minha boca a primeira versão, para que me dissessem se errei. Mas é tarde. A vida separou alguns; a morte levou outros tantos. Neste momento recordo Joaquim Soeiro Pereira Gomes e Carlos Pato. (REDOL, 1979, p. 21-22)

As mudanças que ajustariam o texto "à gesta popular" teriam como ouvintes dignos justamente autores que se constituiriam como receptores em primeira mão do romance - Gomes e Pato. Curioso é notar que, no caso do primeiro, é possível flagrar uma preocupação que converge para os intentos de Redol, quais sejam, os de aferir o caráter da produção antes de esta tomar a forma de livro. De acordo com relato de Ricciardi (1999, p. 90), Gomes teria lido versões preliminares de seu primeiro romance, Esteiros (1941), “a um grupinho de operários para com eles veri- 
ficar a clareza e a compreensão do texto, que eram um imperativo dos escritores neorrealistas.” É bem certo, portanto, que o problema da recepção de Avieiros passe por uns tais critérios e que a assunção dessa divulgação prévia, por parte de Redol, sinalize que valores desejava transmitir e, claro está, a qual destinatário.

No desenrolar de sua carreira literária, que consolida o estatuto do escritor em vários sentidos, Redol revela a autoconsciência que antes lhe faltara. Disso é ilustrativo o papel que, com veemência, imputa-se a Fan$g a$, conforme o prefácio escrito mais de duas décadas depois:

Na barra da história do meu tempo, este livro é um ato de acusação. Jurei pela minha honra dizer a verdade e só a verdade. Tenho-o feito lealmente, sem baixar os olhos. Todos sabem o que eu amo, todos sabem o que me repugna. Não é difícil entender-se o que escrevo e por que escrevo. E também para quem escrevo. Daí apontarem-me como um escritor comprometido. Nunca o neguei: é verdade. Mas também é verdade que todos os escritores o são. Não conheço homens assépticos, desodorizados e incolores. (REDOL, 1980, p. 33)

Reconhecido pelo crítico presencista João Gaspar Simões como "obra-prima dentro desse gênero [do romance de tese]", Fanga é a denúncia da prática exploratória de tons feudais em que os senhores de terra eram os grandes beneficiados (SIMÕES apud SALEMA, 1980, p. 47). ${ }^{18}$ Já é nítida, nessa passagem, a voz do escritor afirmado diante de si mesmo, do seu trabalho e do seu público. Reiteradas as suas convicções, vêse um homem consciente do dinamismo da realidade circundante (a respeito, cf. SÁNCHEZ VÁZQUEZ, 2011, p. 108), mas que, nem por isso, abre mão das motivações que num primeiro momento o conduziram ao romance de denúncia. Para além disso, reforça a condição engajada de toda e qualquer produção literária, sendo que a sua, de Redol, não hesita em revelar-se como tal, bem como as defesas que faz. É um público capaz de respeitar esse contrato que o autor quer para si, consciente ou em vias de conscientização, uma vez que "Ninguém continua a ser exatamente como era depois de ter sido abalado por uma verdadeira obra de arte.” (SÁNCHEZ VÁZQUEZ, 2011, p. 107) Se o escritor é comprometido, é de um público fiel que ele necessita, do que Redol, a essa altura, parece dispor, e essa é a ilação que se pode tirar do virulento discurso do

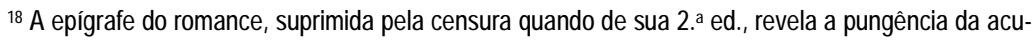
sação feita pelo autor: "Fanga - sombra da Idade Média projetada nos nossos dias. Senhores vivendo da terra sem nada lhe darem. Servos fecundando a terra sem nada receberem." (REDOL, 1980, p. 43)
} 
romancista. Ainda na linha da literatura como missão, o escritor vilafranquense arremata "À Maneira de Prefácio":

Sou demasiado modesto, e também orgulhoso até ao desprezo, para que alguém me leve ao espelho dos bacocos. Todas as costelas que me arqueiam o esqueleto vêm de camponês e os meus antepassados sempre desconfiaram da fartura.

É por isso que a minha charrua continua a lavrar nunca campo de pedras. (REDOL, 1980, p. 37)

Homem por toda a vida avesso às frivolidades que os círculos literários podem proporcionar, Redol insiste nas vias alternativas e vanguardistas por que caminha a sua literatura. A imagem do "campo de pedras", assim, tanto indica uma ordem estabelecida que ao autor parece muito pouco alvissareira (isto é, o "Estado Novo" português) quanto as dificuldades de difundir o seu discurso comprometido e emancipador, justamente porque num campo de alienação. Assim, é custoso chegar a outra conclusão senão a de que Redol tem como destinatário da sua produção tanto o que compartilha das convicções estéticas, ideológicas e morais do autor, como, também, aquele que se busca conscientizar por meio precisamente da ficção, num anelo que, no que contém de utopia, contém de dignidade.

\section{REFERÊNCIAS BIBLIOGRÁFICAS}

AUERBACH, E. Figura. São Paulo: Ática, 1997.

EAGLETON, T. Marxismo e crítica literária. São Paulo: Unesp, 2011.

ECO, U. Seis passeios pelos bosques da ficção. São Paulo: Cia. das Letras, 1999.

ISER, W. The Act of Reading: a theory of aesthetic response. Baltimore: Johns Hopkins University Press, 1978.

LOSA, M. L. Neorrealismo e Populismo: a questão do destinatário. In: GRAÇA, J. (Dir.). Encontro Neorrealismo: reflexões sobre um movimento: perspectivas para um museu. Vila Franca de Xira: Museu do Neorrealismo; Câmara Municipal de Vila Franca de Xira, 1999, p. 181-194.

JOUVE, V. A leitura. São Paulo: UNESP, 2002.

MEDEIROS, N. Edição e editores: o mundo do livro em Portugal: 19401970. Lisboa: Imprensa de Ciências Sociais, 2010. 
NAMORA, F. Carta aberta a Alves Redol. Vértice. Coimbra, v. 30, n. 322-323, p. 853-866, nov.-dez. 1970.

QUEM Conhece Redol? Vértice. Coimbra, v. 30, n. 322-323, p. 936-945, nov.-dez. 1970.

REDOL, A. À maneira de prefácio. In: ___ Fanga. 10. ed. Mem Martins: Europa-América, 1980, p. 29-41.

. Breve história de um romance. In: __. Avieiros. 2. ed. Mem Martins: Europa-América, 1979, p. 13-22.

. Breve memória para os que têm menos de 40 anos ou para quantos já esqueceram o que aconteceu em 1939. In: Gaibéus: romance.

6. ed. ref. Mem Martins: Europa-América, 1965, p. 13-36.

REIS, C. O conhecimento da literatura: introdução aos estudos literários. 2. ed. Coimbra: Almedina, 2001.

. Textos teóricos do Neorrealismo Português. Lisboa: Seara Nova; Comunicação, 1981.

RICCIARDI, G. Soeiro Pereira Gomes: uma biografia literária. Lisboa: Caminho, 1999.

SALEMA, A. Alves Redol: a obra e o homem. Lisboa: Arcádia, 1980.

SÁNCHEZ VÁZQUEZ, A. As ideias estéticas de Marx. 3. ed. São Paulo: Expressão Popular, 2011.

SILVA, G. da. Alves Redol e o Grupo Neorrealista de Vila Franca. Lisboa: Caminho, 1990.

SODRÉ, N. W. Ofício de escritor: dialética da literatura. Rio de Janeiro: Civilização Brasileira, 1965.

TORRES, A. P. O movimento neorrealista em Portugal na sua primeira fase. Lisboa: Instituto de Cultura e Língua Portuguesa, 1977.

TROTSKI, L. Literatura e revolução. Rio de Janeiro: Jorge Zahar, 2007. 